\title{
Prevalence and sociodemographic characteristics associated with benzodiazepines use among community dwelling older adults: The Bambui Health and Aging Study (BHAS)
}

\author{
Prevalência e características sociodemogiráficas \\ associadas ao uso de benzodiazepínicos por idosos \\ residentes na comunidade: Projeto Bambuí
}

\section{Jussara Mendonça Alvarenga,, 1,2 Antônio Ignácio de Loyola Filho,, 1,2 Josélia Oliveira Araújo Firmo,,1,2 Maria Fernanda Lima-Costa,,1,2, Elizabeth Uchoa $a^{1,2,4}$}

\begin{abstract}
Objectives: To assess the prevalence and sociodemographic characteristics associated with benzodiazepine use among communitydwelling older adults. Method: 1606 subjects, aged $\geqslant 60$ years, corresponding to $92 \%$ of the residents of Bambui city, participated in this study. The information about medication use was obtained by means of a standard interview and the review of medication packaging. Substances were classified using the Anatomical Therapeutic Chemical Index. Results: The prevalence of benzodiazepine current use was $21.7 \%$ (26.7\% among females and 14.0\% among males). From these, $68.7 \%$ had been taking the medication for over one year, $31.3 \%$ for over five years and $53.2 \%$ were using long half-life benzodiazepines. The medication most frequently used was bromazepam (35.6\%), followed by diazepam (22.5\%), clonazepam (12.6\%) and lorazepam (7.8\%). After adjustment for confounders, female gender $(R P=1.93 ; C 195 \%=1.51-2.46)$ was the only sociodemographic characteristic found to be independently associated with substance consumption. Conclusions: The prevalence of benzodiazepine use in the study population was high, but within the variation observed in developed countries. Chronic use of benzodiazepines and long half-life medications predominated.
\end{abstract}

Descriptors: Elderly; Pharmacoepidemiology; Use of benzodiazepines; Cross-sectional studies; Anxiolitic agents

\begin{abstract}
Resumo
Objetivos: Determinar a prevalência e características sociodemográficas associadas ao uso de benzodiazepínicos entre idosos residentes na comunidade. Método: Participaram deste estudo transversal 1.606 indivíduos, que correspondem a 92\% do total de residentes na cidade de Bambuí-MG com idade $\geqslant 60$ anos. As informações sobre uso de medicamentos foram obtidas por meio de entrevista padronizada e verificação da embalagem. A classificação do princípio ativo foi baseada no Anatomical Therapeutic Chemical Index. Resultados: A prevalência do uso de benzodiazepínicos foi de 21,7\% (26,7\% entre as mulheres e 14,0\% entre os homens); 68,7\% faziam uso do medicamento há pelo menos um ano, 31,3\% há pelo menos cinco anos e 53,2\% faziam uso de benzodiazepínicos de meia-vida longa. O medicamento de uso mais comum foi o bromazepam (35,6\%), seguido pelo diazepam (22,5\%), clonazepam $(12,6 \%)$ e lorazepam (7,8\%). Após ajuste para variáveis de confusão, sexo feminino foi o único fator independentemente associado ao uso de benzodiazepínico ( $R P=1,93$; IC95\% =1,51-2,46). Conclusões: A prevalência do consumo de benzodiazepínicos na população estudada foi alta, mas dentro da variação observada em países desenvolvidos. O uso crônico e o uso de benzodiazepínicos de meia-vida longa foi predominante.
\end{abstract}

Descritores: Idoso; Farmacoepidemiologia; Uso de benzodiazepínicos; Estudos transversais; Ansiolíticos

1 Public Health and Aging Research Group, Fundação Oswaldo Cruz (FIOCRUZ) and Universidade Federal de Minas Gerais (UFMG), Belo Horizonte (MG), Brazil

2 Post-Graduate Program in Health Sciences, Institute René Rachou, Fundação Oswaldo Cruz (FIOCRUZ), Belo Horizonte (MG), Brazi

3 Departament of Preventive and Social Medicine, Medical School, Universidade Federal de Minas Gerais (UFMG), Belo Horizonte (MG), Brazil

4 Mental Health Departament, Medical School, Universidade Federal de Minas Gerais (UFMG), Belo Horizonte (MG), Brazil

Finanancing: Financer of Studies and Projects (FINEP).

Conflict of interests: M. F. Lima-Costa and E. Uchôa are funded researchers of the Conselho Nacional Desenvolvimento Científico e Tecnológico (CNPq).

Submitted: February 14, 2007

Accepted: June 20, 2007

\section{Correspondence}

Jussara Alvarenga

Laboratório de Epidemiologia e Antropologia Médica

Instituto René Rachou da Fundação Oswaldo Cruz

Av. Augusto de Lima, 1715

30190-002 Belo Horizonte, MG, Brazi

E-mail: lima-costa@cpqrr.fiocruz.br 


\section{Introduction}

Fear or anxious apprehension are emotional responses to danger or threat. For thousands of years humans have used diverse substances to alleviate this negative emotional state. One of the first tranquilizers used, and which continues to be consumed until today, is alcohol; others followed, such as barbiturates, bromides and meprobamates. ${ }^{1}$ Since they were released in the market in 1960, the benzodiazepines became the most prescribed drugs and the most used to combat anxiety and insomnia in the whole world. ${ }^{2}$ This use stemmed from their efficiency, security, and lower potential to cause dependence, their tolerance as well as wide therapeutic applicability. ${ }^{3}$

Nonetheless, the use of benzodiazepines has been associated with several adverse effects, such as motor disturbances, falls, daytime sleepiness and cognitive decline. The modifications in metabolism which accompany the ageing process make the elderly an especially vulnerable age group to these undesirable medication effects, ${ }^{3}$ which are even worse when long half-life benzodiazepines are used for prolonged periods, especially when not accompanied by an adequate clinical monitoring. ${ }^{4}$

The use of benzodiazepines is frequent among the elderly. Although a decrease in prescribing benzodiazepines for the elderly has been observed in some studies, 5,6 population-based studies continue to demonstrate high prevalences in the consumption of these medications in developed countries, and levels ranged from $20.0 \%$ in Canada $^{7}$ to $31.9 \%$ in France. $^{8}$ With respect to the type of benzodiazepines most used, there is a diversity of results in different countries. ${ }^{8-10}$ It has been described that female gender is the sociodemographic characteristic most consistently found to be associated with the use of benzodiazepines among the elderly. 5,6,8,9,11

Brazilian epidemiological studies on the use of benzodiazepines among the elderly dealt with selected populations and/or investigated specific associations, such as the occurrence of falls. ${ }^{12-15}$ Populationbased studies on the consumption of these medications have been accomplished on younger individuals, ${ }^{16,17}$ and the benzodiazepine consumption was investigated in a much wider context, which was the use of psychopharmacs. ${ }^{18-20}$ The population-based studies showed benzodiazepines as the most commonly used psychopharmacs in the adult population, ${ }^{17-20}$ and among these, Diazepam was the most used chemical substance. ${ }^{16,18,19}$ In these studies, the consumption of benzodiazepines was higher among women, ${ }^{16,17}$ among older subjects and among the wealthy. ${ }^{17}$

To our knowledge, there are no Brazilian studies on the profile of use of benzodiazepines among community-dwelling older adults. As the use of these medications among the elderly is more frequent and involves greater risks and taking into consideration the rapid aging of the Brazilian population, ${ }^{21}$ it is important to investigate this question in greater detail in this country.

The present study has the following objectives: 1) to determine the prevalence of benzodiazepine use among community-dwelling older adults; 2) to assess the prevalence of the chemical substances most used; and 3) to examine the sociodemographic characteristics associated with benzodiazepine consumption.

\section{Method}

\section{Study area and population}

This study is part of the baseline of the Bambuí Health and Aging Study, which is a population-based cohort study carried out in the city of Bambuí, which is situated in the state of Minas Gerais, Southeastern Brazil. At the time of the study, the city of Bambuí had approximately 21,000 inhabitants, of which 15,000 lived in the urban area. Life expectancy was 70.2 years and the leading death causes among the elderly were cerebrovascular diseases, Chagas' disease and ischemic heart disease. ${ }^{22}$
All the city inhabitants aged 60 years or older on the first of January of 1997 were identified through census and selected to constitute the baseline of the cohort study. Of the 1,742 dwellers in the selected age group, 1,606 (92.2\%) participated in the baseline study and were selected for the present study.

\section{Variables}

The data collection was performed at the participant's domicile, by means of a questionnaire applied by trained interviewers. If the selected older adult was not able to respond to the questionnaire due to health problems or cognitive deficit, a close relative or caregiver responded instead $(5.6 \%$ of the interviews were answered by a proxy). ${ }^{22}$

The dependent variable of the study was the use of benzodiazepines. For its construction, information was obtained about the use of any medication in the last 90 days. In case of a positive answer, he/she was asked to report the name and the dosage of the medication, for how long it had been used and if it had been prescribed by a physician or not. The interviewee was then asked to show the prescription and/or the medication packaging for confirmation. Based on the name and dosage, the medications were identified, their principal active components were discovered and later classified according to the Anatomical Therapeutic Chemical Index (ATC Index), developed by the World Health Organization Collaborating Centre for Drugs Statistics Methodology. ${ }^{23}$ This system of codification classifies medications according to the anatomical site where they act, their therapeutic action and pharmacological and chemical properties. The use of the ATC classification system is recommended to facilitate the international comparison of results.

The sociodemographic characteristics considered in this study were gender, age (60-69 years; 70-79 years e 80+ years), marital status (married/consensual union; widower; single/separated/divorced), educational level (number of complete schooling years) and monthly family income (in minimum wages applied at the time of the study).

\section{Data analysis}

Data analysis consisted of determining the prevalence of benzodiazepine use by age and gender. The use of these medications was characterized in relation to the quantity consumed, period of use, use of drugs with long half-lives, type of medication used, therapeutic function and principal active ingredient. Non-adjusted analysis for association among the variables was based on Pearson's chi-square test.

Crude and adjusted prevalence rates (PR) were used to examine the associations between the consumption of benzodiazepine and sociodemographic characteristics. The PR were estimated by Robust Poisson Regression. ${ }^{24}$ Data analysis was developed using STATA ${ }^{\circledR}$ (version 7.0) software.

All the study participants signed a term of post-informed consent. The Bambuí Project was approved by the Ethics Committee of the Oswaldo Cruz Foundation (FIOCRUZ).

\section{Results}

Of the 1606 participants in the study, 964 (60.1\%) were women and the average age was 69.3 years $(s d=7.4)$. The predominant age was $60-69$ years $(58.1 \%)$, followed by $70-79$ years $(30.6 \%)$ and 80 years or more (11.3\%).

The prevalence of benzodiazepine use was $21.7 \%$ (348/1606), and was higher among females (26.7\%) than among males (14.0\%) $-p<0.01$. Regarding the prescription, $98.5 \%$ of benzodiazepines used have been prescribed by a physician. Among the medication users, only $3.2 \%$ had seen a psychiatrist in the prior 12 months, while $94.5 \%$ had seen other specialists in the same period. 
In Figure 1 the distribution of use of benzodiazepines by gender and age group is presented. Among males, the prevalence of the use of benzodiazepines increased with age, from $11.6 \%$ in the $60-69$ years old group up to $13.5 \%$ in the $70-79$ years group and $28.6 \%$ in the $80+$ years group $(p=0.001)$. Among females, the use of the medication did not significantly differ between the three age groups considered $(28.1 \%, 24.8 \%$ and $25.0 \%$, respectively in the age group 60-69, 70-79 and $80+$ years; $p=0.533$ ).

Among the 348 benzodiazepine users, approximately two-thirds $(68.7 \%)$ had used the medication for one or more years and one-third $(31.3 \%)$ had used the medication for five years or more, as shown in Table 1 . These percentages were similar for males and females $(67.8 \%$ and $69.0 \%$ and 35.6 and $29.8 \%$, respectively) $-p=0.453$. In relation to age, the observed differences were not statistically significant $(p=0,384)$, but it is important to point out that there was a gradual decline in the prevalence of the prolonged use of benzodiazepines ( $5+$ years) with the increase of age (from $34 \%$ to $29 \%$ and $25 \%$ for the age groups of 60-69, 70-79 e 80+ years old, respectively).

Long-half life benzodiazepines predominated (53.2\%) among medication users. This consumption was similar among women (51.2\%), when compared to men (58.9\%) - $p=0.206$. The prevalence of long half- life benzodiazepine use ranged from $37.5 \%$ (age group $80+$ years) to $56.0 \%$ (age group $60-69$ years) and $55.0 \%$ (age group $70-79$ years) - $p=0.064$ (Table 2).

Considering their therapeutic function, the most commonly used benzodiazepine derivatives were anxiolytics (76.8\%), followed by anticonvulsivants (12.6\%) and hypnotics/sedatives (10.6\%). In terms of chemical formulation, Bromazepam was the most common active ingredient (35.6\%), followed by Diazepam (22.5\%), Clonazepam (12.6\%) and Lorazepam (7.8\%) - Figure 2.

The results of the analysis of the sociodemographic factors associated with the use of benzodiazepines are presented in Table 3. In the non-adjusted analysis, female gender $(P R=1.90 ; 95 \% \mathrm{Cl}=1.53-2.37)$ and being a widower ( $P R=1.32 ; 95 \% \mathrm{Cl}=1.08-1.61)$ presented positive and significant associations with the use of benzodiazepines. After adjustment for age, marital status, schooling and monthly family income, only female gender remained associated with the use of the medication $(P R=1.93 ;$ IC $95 \%=1.51-2.46)$.

\section{Discussion}

The prevalence of benzodiazepines consumption in the studied population $(21.7 \%)$ was similar to that observed in two studies conducted among elderly Canadians, ${ }^{6,25}$ higher than the observed among elderly North Americans(10\%) $)^{5,9}$ and lower than that observed in a French community (31.0\%). ${ }^{8}$ Compared with other Brazilian studies, the use of benzodiazepines among older adults was higher than that

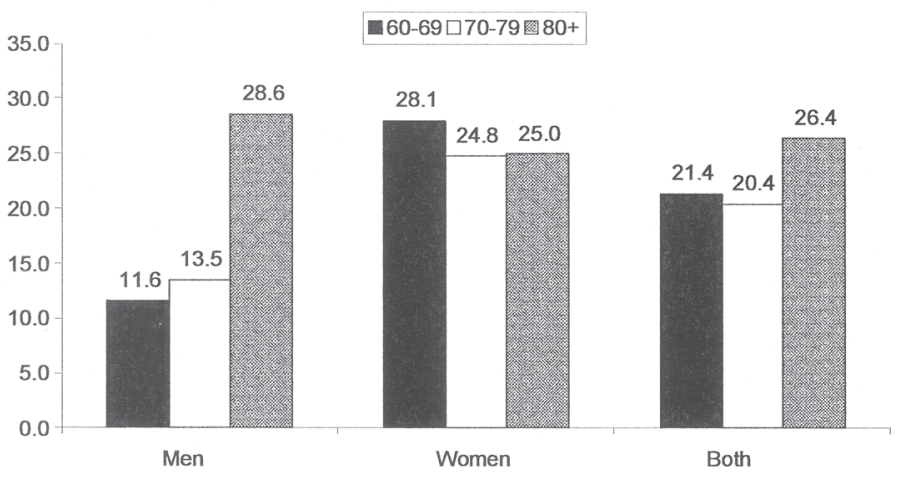

Figure 1 - Baseline results of benzodiazepines use prevalence (\%) among participants of the Bambui cohort study
Table 1 - Baseline results of duration of benzodiazepines chronic use among older adults from the Bambuí cohort study

\begin{tabular}{|c|c|c|c|c|c|c|c|}
\hline \multirow{3}{*}{$\begin{array}{c}\text { Gender and } \\
\text { age }\end{array}$} & \multicolumn{6}{|c|}{ Duration of use } & \multirow{3}{*}{$\stackrel{p}{\text { value }^{a}}$} \\
\hline & \multicolumn{2}{|c|}{$<1$ year } & \multicolumn{2}{|c|}{$1-4$ years } & \multicolumn{2}{|c|}{5 and over } & \\
\hline & $\mathbf{n}$ & $(\%)$ & $\mathbf{n}$ & $(\%)$ & $\mathbf{n}$ & (\%) & \\
\hline Male & 29 & (32.2) & 29 & (32.2) & 32 & $(35.6)$ & \\
\hline Female & 80 & $(31.0)$ & 101 & (39.2) & 77 & $(29.8)$ & 0.453 \\
\hline $60-69$ years & 66 & $(33.0)$ & 66 & $(33.0)$ & 68 & $(34.0)$ & \\
\hline $70-79$ years & 28 & $(28.0)$ & 43 & $(43.0)$ & 29 & $(29.0)$ & \\
\hline 80 and over & 15 & (31.3) & 21 & $(43.8)$ & 12 & $(25.0)$ & 0.384 \\
\hline Total & 109 & (31.3) & 130 & (37.4) & 109 & (31.3) & \\
\hline
\end{tabular}

${ }^{a}$ Pearson's chi- square test

observed in the adult population of the city of Pelotas-RS ${ }^{17}$ and similar to that verified among the elderly population of a social center in Rio de Janeiro. ${ }^{13}$

Regarding prescription, it is important to highlight that only $3 \%$ of benzodiazepine users had seen a psychiatrist in the prior year, while 95\% had seen another specialist in the same period, suggesting that most of the prescriptions had been prescribed by non-psychiatrist physicians. The predominance of prescriptions of benzodiazepine by other specialists had also been observed in a cohort of elderly Americans. ${ }^{5}$

The most commonly used benzodiazepine by older adults of Bambuí was Bromazepam. In the study population predominated the use of benzodiazepine with therapeutic anxiolytic action, as well the use of long half-life medications. The predominance of Bromazepam use was paralleled by another Brazilian study, ${ }^{13}$ but is not consistent with that observed in developed countries. ${ }^{7-9}$ Of note, the use of benzodiazepines with long half-lives is considered inappropriate for the use in older adults since the risks are higher than the possible therapeutic benefits. ${ }^{26,27}$ With the metabolic alterations of an aging organism such as decrease of renal excretion and hepatic metabolism, fall in the albumin serum level and in the volume of body fluids, decrease of the muscle mass and increase of fat, there is an increase of the plasmatic levels and of the half-life of many drugs. ${ }^{12,28}$ Thus, the effect of the medication, which is already of slow elimination, is exacerbated, causing possible daytime sleepiness, falls and cognitive deficit. ${ }^{29}$

The use of benzodiazepines observed in this study presented a pattern which is compatible with chronic use (approximately two-thirds of the older adults have been using the medication for at least 12 months). Even though the present study has

Table 2 - Baseline results of long half-life benzodiazepines use among older adults from the Bambui cohort study

\begin{tabular}{|c|c|c|c|c|c|}
\hline \multirow[t]{3}{*}{ Gender and age } & \multicolumn{4}{|c|}{$\begin{array}{l}\text { Use of long half- life } \\
\text { benzodiazepines }\end{array}$} & \multirow[t]{3}{*}{ p value ${ }^{a}$} \\
\hline & \multicolumn{2}{|c|}{ No } & \multicolumn{2}{|c|}{ Yes } & \\
\hline & n & $(\%)$ & $\mathbf{n}$ & $(\%)$ & \\
\hline Male & 37 & (41.1) & 53 & $(58.9)$ & \\
\hline Women & 126 & $(48.8)$ & 132 & (51.2) & 0.206 \\
\hline $60-69$ years & 88 & $(44.0)$ & 112 & $(56.0)$ & \\
\hline $70-79$ years & 45 & $(45.0)$ & 55 & $(55.0)$ & \\
\hline 80 and over & 30 & (62.5) & 18 & (37.5) & 0.064 \\
\hline Total & 163 & $(46.8)$ & 185 & (53.2) & \\
\hline
\end{tabular}

a Pearson's chi- square test 




Figure 2 - Baseline results of benzodiazepines distribution among older adults from the Bambui cohort study

not considered the number of daily doses and the dosage of benzodiazepines, this result is worrisome. The chronic use of these medications, in itself, is not recommended for older adults as it increases the risks of side-effects, such as dependence and cognitive dysfunction. ${ }^{3,30}$

Studies of older adults in developed countries have consistently presented a positive and independent association between female gender and the use of benzodiazepine, ${ }^{5,6,8,9,11}$ although this association has not been observed by all the authors. ${ }^{7}$ The results of the present study are consistent with previous observations regarding a positive association between female gender and the use of benzodiapines. This finding persisted after adjustment for other relevant sociodemographic characteristics. The hypotheses formulated to explain this association are related to health conditions and the use of health services, including issues of doctor-patient relationship. Because women live longer than men, they suffer more strongly and more frequently than men from the psychological effects of aging, ${ }^{30}$ and from health problems linked to psychic

Table 3 - Baseline results of benzodiazepine use and its association with sociodemographic characteristics among older adults from the Bambui cohort study

\begin{tabular}{|c|c|c|c|c|}
\hline \multirow{2}{*}{$\begin{array}{c}\text { Sociodemographic } \\
\text { characteristics }\end{array}$} & \multicolumn{2}{|c|}{ Benzodiazepine use } & \multicolumn{2}{|c|}{ Prevalence Rates (PR) ${ }^{a}$} \\
\hline & $\begin{array}{c}\text { Yes } \\
(n=348) \%\end{array}$ & $\begin{array}{c}\text { No } \\
(n=1,258) \%\end{array}$ & Crude & Adjusted $^{b}$ \\
\hline \multicolumn{5}{|l|}{ Gender } \\
\hline Male & 14.0 & 86.0 & 1.00 & 1.00 \\
\hline Female & 26.7 & 73.3 & $1.90(1.53-2.37)$ & $1.93(1.51-2.46)$ \\
\hline \multicolumn{5}{|l|}{ Age group ( years) } \\
\hline $60-69$ & 21.4 & 78.6 & 1.00 & 1.00 \\
\hline $70-79$ & 20.4 & 79.6 & $0.95(0.77-1.18)$ & $0.95(0.77-1.17)$ \\
\hline $80+$ & 26.4 & 73.6 & $1.23(0.94-1.62)$ & $1.19(0.90-1.58)$ \\
\hline \multicolumn{5}{|l|}{ Marital status } \\
\hline Married & 19.8 & 80.3 & 1.00 & 1.00 \\
\hline Widowed & 26.0 & 74.0 & $1.32(1.08-1.61)$ & $1.03(0.82-1.29)$ \\
\hline Single/Separated & 17.9 & 82.1 & $0.90(0.67-1.22)$ & $0.82(0.60-1.11)$ \\
\hline \multicolumn{5}{|l|}{ Schooling (Years) } \\
\hline Illiterate & 20.3 & 79.7 & 1.00 & 1.00 \\
\hline $1-3$ & 23.2 & 76.8 & $1.15(0.91-1.44)$ & $1.17(0.93-1.48)$ \\
\hline $4+$ & 21.6 & 78.4 & $1.07(0.84-1.34)$ & $1.14(0.89-1.45)$ \\
\hline \multicolumn{5}{|l|}{ Monthly family income ${ }^{c}$} \\
\hline$<2$ & 20.3 & 79.7 & 1.00 & 1.00 \\
\hline $2-3$ & 24.1 & 75.9 & $1.19(0.95-1.49)$ & $1.20(0.96-1.51)$ \\
\hline$\geq 4$ & 20.4 & 79.6 & $1.01(0.79-1.29)$ & $1.03(0.79-1.33)$ \\
\hline
\end{tabular}

${ }^{a}$ Prevalence Rates (95\% confidence interval) were estimated by Robust Poisson Regression

${ }^{b}$ Adjusted by all variables included in the model (1.590 subjects participated in final analysis)

${ }^{c}$ In Brazilian minimum wages (each $=$ US $\$ 120.00$ ) 
disorders. ${ }^{11,30}$ Also, women have more contact with health care services, ${ }^{11,30}$ they talk about their health problems more easily during consultations to their physicians, they express their desire for a prescription more clearly and they demonstrate a greater acceptance of psychopharmacs (among which are included the benzodiazepines). ${ }^{30}$

In the present study, being a widow was positively associated with the use of benzodiazepines in the univariate analysis, but the association disappeared after adjustment for confounders, which was also observed in other studies. ${ }^{11}$ Since, in this population, the female gender and being a widow were strongly correlated, the association between the latter and the use of benzodiazepines was confounded by gender.

Some advantages as well as limitations of the study deserve further discussion. The present paper was conducted among communitydwelling older adults. Population-based studies are less prone to selection bias than studies conducted in selected populations. Another advantage in this study was the high response rate, assuring its internal validity. The cross-sectional design adopted in the study is adequate to prevalence assessment, but it does not allow establishing temporal relationships between the sociodemographic characteristics investigated and the use of benzodiazepines, which is one of the limitations of the present study. It is important to note that the information about benzodiazepine use was obtained by means of interviews, focusing on the use of medications in the prior 90 years. This period is longer than that usually adopted in pharmaco-epidemiological studies. Nonetheless, this fact might not have influenced the comparability of our results because 1 ) the report of medication use was confirmed by the medication packaging and/or medical prescription; 2) the chronic use of the medication predominated among the participants of the study.

In summary, the prevalence of benzodiazepines in the study's population was high, but within the variation observed in developed countries. Chronic use and long-half life benzodiazepines were predominant. Although this use has decreased in the oldest group (80+ years old), which might possibly reflect greater caution in the prescription of benzodiazepines, this pattern is considered inadequate even for younger elderly. The results of this paper point out to the need of further investigation in order to verify if the results reflect characteristics which are peculiar to the area studied or if they are generalizable for other populations of older adults of this country.

\section{Acknowledgements}

This study was financed by the Financer of Studies and Projects (FINEP).

\section{References}

1. Marcolin MA. Interações farmacológicas com drogas psiquiátricas. Rio de Janeiro: MEDSI; 1998.

2. Llorente MD, David D, Golden AG, Silverman MA. Defining patterns of benzodiazepine use in older adults. J Geriatr Psychiatry Neurol. 2000;13(3):150-60

3. Gilman G. As bases farmacológicas da terapêutica. Hardman JG, Limbird LE, editores. 10a. ed. Rio de Janeiro: McGraw-Hill; 2003.

4. Kaplan HI, Sadock BJ. Tratado de Psiquiatria. 6a. ed. Porto Alegre: Artes Médicas; 1999.

5. Blazer D, Hybels C, Simonsick E, Hanlon JT. Sedative, hypnotic, and antianxiety medication use in an aging cohort over tem years: a racial comparison. J Am Geriatr Soc. 2000;48(9):1073-9.

6. Tu K, Mamdani MM, Hux JE, Tu JB. Progressive trends in the prevalence of benzodiazepine prescribing in older people in Ontario, Canada. J Am Geriatr Soc. 2001;49(10):1341-5.

7. Mayer-Oakes AS, Kelman G, Beers MH, De Jong F, Matthias R, Atchison KA, Luben JE, Schweitzer SO. Benzodiazepine use in older, community-dwelling southern Californians: prevalence and clinical correlates. Ann Pharmacother. 1993;27(4):416-21.

8. Fourrier A, Letenneur L, Dartigues JF, Moore N, Begaud B Benzodiazepine use in an elderly community-dwelling population. Eur J Clin Pharmacol. 2001;57(5):419-25.

9. Gleason PP, Schulz R, Smith NL, Newsom JT, Kroboth PD, Kroboz FJ, Psaty BM. Correlates and prevalence of benzodiazepine use in communitydwelling elderly. J Gen Intern Med. 1998;13(4):243-50.

10. Van Hulten R, Leufkens HG, Bakker A. Use patterns of benzodiazepines in a Dutch community: a 10-year follow-up. Pharm World Sci. 1998;20(2):78-82

11. Jorm AF, Grayson D, Creasey H, Waite L, Broe GA. Long-term benzodiazepine use by elderly people living in the community. Aust N Z Public Health. 1999;24(1):7-10.

12. Mosegui GB, Rozenfeld S, Veras RP, Vianna CM. Avaliação da qualidade do uso de medicamentos em idosos. Rev Saude Publica. 1999;33(5):437-44.

13. Huf G, Lopes CS, Rozenfeld S. O uso prolongado de benzodiazepínicos em mulheres de um centro de convivência para idosos. Cad Saude Publica. 2000;16(2):351-62.

14. Coutinho ES, Silva SD. Uso de medicamentos como fator de risco para fratura grave decorrente de queda em idosos. Cad Saude Publica. 2002;18(5):1359-66.

15. Rozenfeld, S. Prevalência, fatores associados e mal uso de medicamentos entre os idosos: uma revisão. Cad Saude Publica. 2003;19(3):717-24

16. Wortmann AC, Grudtner MC, Fialho AF, Jardim Neto JC, Shaefer LG, Sehn F, Pechansky F. Soibelman M. Consumo de benzodiazepínicos em Porto Alegre. Rev Ass Med Brazil. 1994;40(4):265-70.

17. Lima MS, Hotopf M, Mari JJ, Beria JU, Bastos AB, Mann A. Psychiatric disorder and the use of benzodiazepines: an example of the inverse care law from Brazil. Soc Psychiatr Epidemiol. 1999;34(6):316-22.

18. Almeida LM, Coutinho ES, Pepe VL. Consumo de psicofármacos em uma região administrativa do Rio de Janeiro: a Ilha do Governador. Cad Saude Publica. 1994;10(1):5-16.

19. Noto AR, Carlini EA, Mastroianni PC, Alves VC, Galduroz JC, Kuroiwa W, Czimar J, Costa A, Faria MA, Hidalgo SR, Assis D, Nappo SA. Analysis of prescription and dispensation of psychotropic medications in two cities in the State of São Paulo, Brazil. Rev Bras Psiquiatr. 2002;24(2):68-73

20. Rodrigues MA, Facchini LA, Lima MS. Modificações nos padrões de consumo de psicofármacos em localidade do Sul do Brasil. Rev Saude Publica. 2006;40(1):107-14

21. Carvalho JA, Garcia RA. O envelhecimento da população brasileira: um enfoque demográfico. Cad Saude Publica. 2003;19(3):725-33.

22. Costa MF, Uchoa E, Guerra HL, Firmo JO, Vidigal PG, Barreto SM. The Bambui Health and Ageing Study (BHAS): Methodological approach and preliminary results of a population-based cohort study of the Brazil. Rev Saude Publica. 2000;34(2):126-35.

23. WHO - Collaborating Centre for Drugs Statistics (Oslo, Norway). Anatomical Therapeutical Chemical (ATC) classification index with Defined Daily Doses (DDDs). [cited Feb 2006] Available at: http:// www.whocc.no/atcddd/

24. Zou G. A modified poisson regression approach to prospective studies with binary data. Am J Epidemiol. 2004;159(7):702-6.

25. Egan M, Moride $\mathrm{Y}$, Wolfson $\mathrm{C}$, Monette J. Long-term continuous use of benzodiazepines by older adults in Quebec: prevalence, incidence and risk factors. J Am Geriatr Soc. 2000;48(7):811-6.

26. Stuck AE, Beers MH, Steiner A, Aronow HU, Rubenstein LZ, Beck JC. Inappropriate medication use in community-residing older persons. Arch Intern Med. 1994:154(19):2195-200.

27. Beers $\mathrm{MH}$. Explicit criteria for determining potentially inappropriate medication use by the elderly. Arch Intern Med. 1997;157(14):1531-6.

28. Williams CM. Using medications appropriately in older adults. Am Family Physician. 2002;66(10):1917-24.

29. Petrovic M, Mariman A, Warie H, Afschrift M, Pevernagie D. Is there a rationale for prescription of benzodiazepines in the elderly? Review of the literature. Acta Clin Belg. 2003;58(1):27-36.

30. Voyer P, Cohen D, Lauzon S, Collin J. Factors associated with psychotropic drug use among community- dwelling old persons: a review of empirical studies. BMC Nursing. 2004;3:3. [cited 15 Feb 2007] Available at: http://www.biomedcentral.com/bmcnurs?page3 